\title{
The Impact of Natural Element's Forms in Emergency Unit Room Toward Nurse Motivation And Attitude During Night Shift: Case Of Santo Borromeus Hospital
}

\author{
Arnanti Primmiana Yuniati ${ }^{1}$, Prabu Wardono ${ }^{2}$, Yuni Maharani ${ }^{3}$ \\ ${ }_{1,2,3}$ Master's Program in Design, Faculty of Arts and Design, Institute of Technology \\ Bandung, Indonesia
}

*arnanti.primiana@gmail.com

Received: 11 February 2017 Final Version Received: 19 July 2018

\begin{abstract}
The importance of medication quality has made many researchers and hospital management tried to research the way to increase nurses work performance. Studies had found that motivation and work attitude in healthcare are critical to boost nurses work performance. Various methods were strived to improve motivation and work attitude, one of them is by applying nature elements. Other research found that nature restores both human physical and mind. The objective of this research is to improve Emergency Unit nurse motivation and attitude by placing nature form both natural and artificial, during night shift. Motivation and attitude can be measured by mood, further, positive mood improves motivation and work attitude. The experiment was held by giving 6 nature form conditions through digital animation walkthroughs as stimuli and evaluated by mood, motivation, and attitude questionaire using 7 scales of T'Likerts. Positive and Negative Affect Schedule (PANAS) is used as mood questionnaire, while motivation and attitude questionnaire adapt from nurses' duties. The research found that mood, motivation, and attitude affect each other. Every nature form in interior stimulates specific mood, motivation, and attitude responses. Besides that, artificial nature form, especially nature form on the floor, is the most preferable to improve nurse motivation and attitude.
\end{abstract}

Keywords: Mood,Motivation, Attitude, Nurse, Nature

\section{INTRODUCTION}

Nurses' tasks have enabled them to frequently and directly interact with their patients. It is therefore understandable that the success of health care services essentially relies on nurses' participation in providing high quality services to their patients according to the latest functional specifications which meet and exceed the customer needs (Mosadeghrad, 2014). Nurses assigned in the Emergency Department for the night shifts have relatively more workload than medical staff in other departments in the same hospitals. This is true based on the fact that the Emergency Department nurses specifically those who are in charge for the night shifts must stay awake throughout the night to control their patients. According to Boughattas and his colleagues (2014), night shifts at hospitals are likely to reduce nurses' sleep quality, life quality, and alertness toward emergency or danger. Furthermore, based on Ansari et al. (2015) research findings, "Emergency Unit Staff suffer from great levels of stress leading to physician burnout and more likelihood of committing errors." Pressure from which nurses suffer can decrease their motivation and change their attitude; as a result, their performance will drop.

Dobre (2013) states that employees' work performance is critical to organization's management because it determines the evolution and achievement of the organization. In other words, performance is the accomplishment of one's works, which are in line with the criteria and goals set by the organization. In relation with hospitals, good performance of nurses means an avenue to 
achieve hospitals' objectives. Some researches indicate that there are three important factors influencing nurses' work performance, namely cognitive (Aghdam et al., 2013), motivation (Adjei et al.,2016) and attitude (Shahab, 2014). With regard to these factors, this study focused on nurses' work motivation and attitude. Work motivation and attitude are psychological construction which cannot be directly observed nor recorded. Because of that, affective observation or mood is required to measure them (Santillan et al., 2012; ToureTillery \& Fishback, 2014).

Since mood can affect work motivation and attitude, efforts must be made to improve performance at the workplace. In hospital, one of the efforts is to improve work motivation and to encourage positive attitude in order to provide better health care services. Said, Abed, and Abdo (2013) stated that physical environment also contributes to nurse' work motivation. Work environment is complex and can affect physical (biological) aspects and psychological responses (perception and mood) and it can also distinguish physical characteristic of an environment (Kamaruzzaman \& Sabrani, 2011). To achieve hospitals' goals, there must be a mutual relationship between hospitals and their medical staff. Hospitals are supposed to provide not only job descriptions and regulations to improve the performance of the organization and to accomplish hospitals' goals but also attention on physical and non-physical factors of the work environment. Furthermore, researchers have been aware of the importance of work environment for work satisfaction and workers' performance (Bringslimark et al., 2012). In this study, improving the quality of work environment was administered by applying nature elements.

According to Keniger (2013), people often turns to nature to restore their physical and psychological well being; however, most people rarely have a chance to spend their time in the nature (Hitchings, 2009). Therefore, nature should be applied on their environment where they spend most of the time, in this study, workplace interior.

Interior applying natural elements have been long studied and proven to affect workers' efficacy and health. Natural elements significantly influence positive psychological, cognitive, physiological, social, and spiritual responses (Keniger, 2013). Furthermore, nature is able to trigger positive mood to improve cognitive competence, attitude, and performance. Thus, this principle is also effective to be applied for nurses (Berman et al., 2008). In addition, natural elements not only increase satisfaction but also reduce stress and help medical staff to face serious pressure. This enables them to improve the quality of their medical services.

Even though this topic is crucial; however, there are only a small number of studies done to examine the influence of physical environment toward nurses' motivation and attitude in a health care institution like hospitals. This statement highlights the fact that focusing on medical staff' psychological aspects are not yet prioritized by the hospital management, specifically the application of natural elements which are believed to be the most effective means to boost nurses' motivation and attitude. Therefore, this study aimed at examining the influence of the form of the natural elements (incidental interaction) and the man-made ones (indirect interaction) towards motivation and attitude of Emergency Department' nurses who work in night shifts. Based on selection processes and surveys, the forms of natural elements considered for this study were real plants and graphic pictures of Epipremnum aureum or golden pothos (also known as devil's ivy or sirih belanda in Indonesian language).

\section{RESEARCH METHOD}

This study was conducted by performing Within Subject Design experiments to find out how work environment affected work motivation and attitude of nurses through mood measurement (Azka, 2016). This method was administered by requesting the respondents to fill out the questionnaire after evaluating the condition of the stimulus.

Digital animation walkthroughs were used as experimental stimuli to allow the researcher to be more flexible in determining the characteristics of the expected spaces and to enable nurses to directly enjoy better spatial experience. According to Musa et al. (2013), animation significantly helps to understand and remember information. The information is implicitly disseminated through image changes, namely changing position, forms, and dynamics. Digital animation walkthroughs were adapted from the setting of Santo Borromeus Hospital's Emergency Department during night time (Figures 1 and 2). Furthermore, stimuli were made by applying 
the forms of real natural elements and the man-made ones on interior elements (floor, wall, ceiling) and soft furnishing with different forms of natural elements as depicted in Figures 3 to 8 .

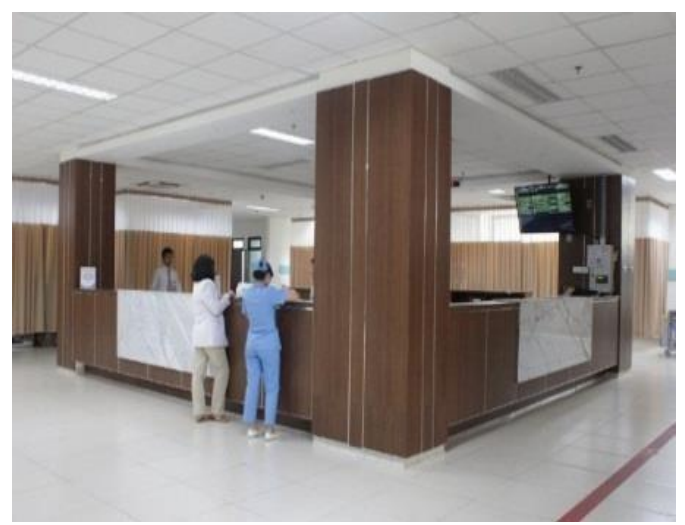

Fig.1: The situation of Emergency Department during night shift

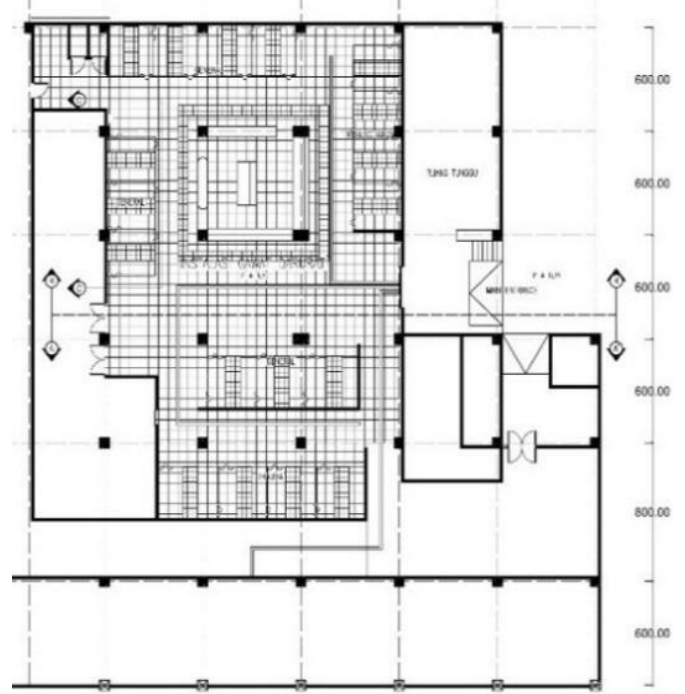

Fig.2: Emergency Department Layout Experimental stimuli used a model of Santo Borromeus Hospital's Emergency Department.

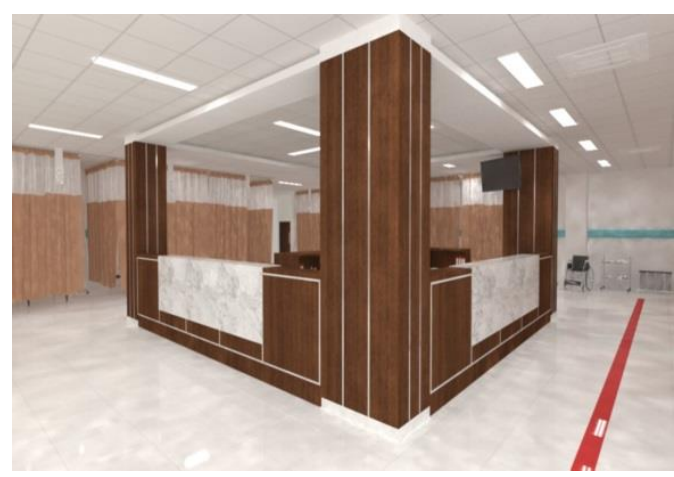

Fig.3: Control variable / condition 1.

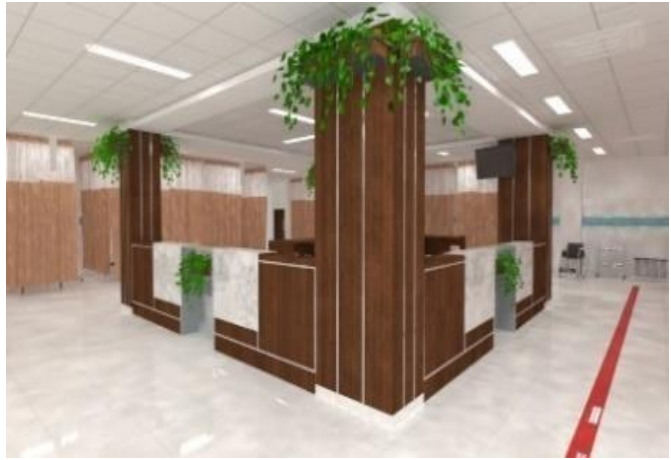

Fig.4: The natural elements / condition 2

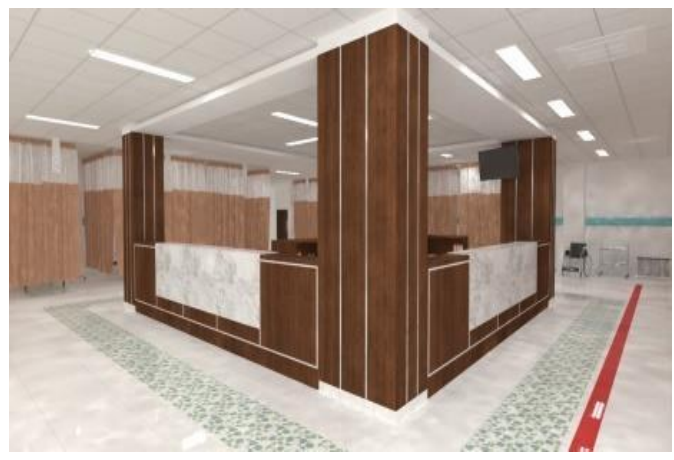

Fig.5: The floor pattern / condition 3.

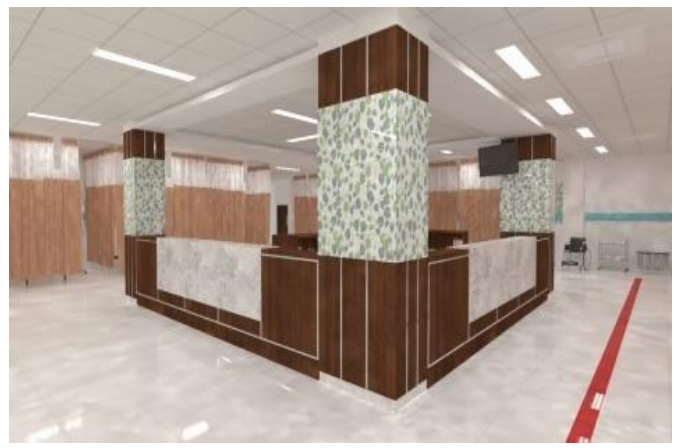

Fig.6: The wall pattern / condition 4

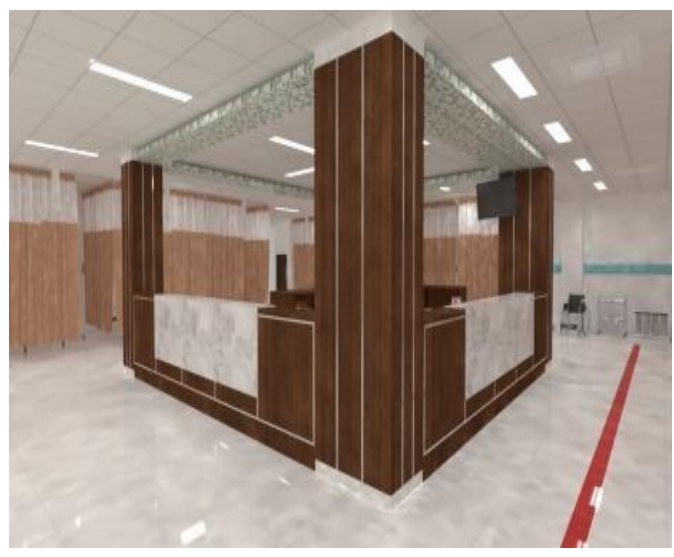

Fig.7: The ceiling pattern / condition 5 


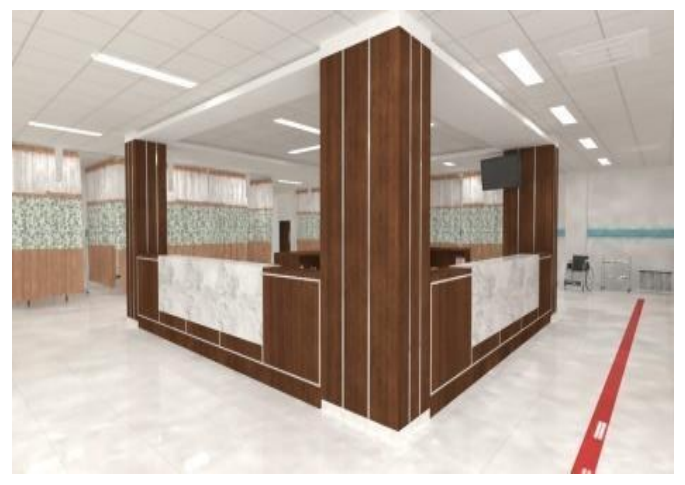

Fig.8: The soft furnishing pattern / condition 6

Digital animation walkthrough is an animation projecting the visual perspective deriving from imaginative human eyes. This animation was utilized in this study to create an effect as if the image was the result of someone's perception of the whole area in the Emergency Department. The animation was developed by emphasizing on every different variable for the same duration, which was 5 seconds observe duration. The average of animation duration was 1 minute 30 seconds depending on the position of walking track and the location of natural elements in the animation. The average walking speed of Indonesians is $1,06 \mathrm{~m} / \mathrm{s}-1,93$ $\mathrm{m} / \mathrm{s}$ (Sorongan, 2014). However, the walking speed in this experiment was $1.67 \mathrm{~m} / \mathrm{s}$ because of the limitation of animation speed that could be not realistic as reducing the walking speed. Also, the eye level height of this animation is adjusted to the average of the Indonesians' height, namely $160 \mathrm{~cm}$. Based on this information, this study applied this standard of eye level.

Before the experiment began, variable was presented in the introduction. Based on the pretest, it was discovered that the participants easily understand the stimulus, which was played twice than the stimulus which was played only once. Thus, in this study, the stimulus was played twice and depicted the image of nurse station area while the participants filled out the questionnaire. For mood and motivation response, respondent was requested to fill both questionnaires after watching the stimulus. Furthermore, in the mood and motivation questionnaires, the order of stimuli were based on the order of the independent variable while the order of the attitude questionnaire was randomized. Based on Creswell's founding, this methods was applied to reduce the chance that differences in experimental conditions strongly bias results (Hastjarjo, 2014). Additionally, black screen was shown in between the gap time when one stimulus was changed to another one in order to neutralize the effect of stimuli before prociding the next one. The time provided for each condition was +5 minutes (including time to fill the questionaire) and the gap time in between animation was +2 minutes. The duration of experiments had lasted for 42 minutes.

This questionnaire aimed at revealing psychological responses of the participants when they evaluated the stimulus. There were three categories of questions in the questionnaires measured in Likert Scale. First, namely 10 positive questions group deriving from Positive and Negative Affect Schedule (PANAS) to measure mood designed by Watson and his colleagues (1988) (attachment B). The second group was 5 motivation evaluation questions (attachment C). Last questionaire was 6 questions to evaluate attitude (attachment D). For measurement, 7 Likert Scale used in these groups consisted of seven options, namely (1) Strongly disagree, (2) Somewhat disagree, (3) Slightly disagree, (4) Abstain, (5) Slightly agree, (6) Somewhat agree, (7) Strongly Agree. The Likert Scale is a psychological measurement device that is used to gauge attitudes, value, and opinions. By dividing it into 7 options, it will generate more sensitive and more accurate magnitude of the measurement. Some nurses, 14 from 39 nurses, became respondents of instrument tests for each questionnaire. As a result, the reliability value for each questionnaire was above 0.9 which means reliable to be use as experiment instrument and all questionnaires were useable.

The rest of the population after deducting with respondents for instrumental test, 25 respondents (above $50 \%$ of the population), participated in the main experiment. According to Fraenkel, Wallen, \& Hyun (2012), a minimum 30 respondents per group for experimental research, in some cases, 15 respondents that are strictly controlled can be adequate. Before experiment began, respondent was requested to fill respondent data questions (attachment A). The number of participants in this experiment was 25 people with the proportion of male and female, 5 and 20 respectively. Some of the requirements to be selected as participants were that the nurses worked in the Emergency Department and had experiences to work in night shifts. The participants age were between 21 to 50 years old. In this study, the majority of respondents 
were 26 to 30 years old ( 7 participants) and 36 to 40 years old ( 7 participants), other, 2 respondents aged $21-25$ years old, 4 respondents aged $31-35$ years old, 2 respondents aged $41-45$ years old, and last, 3 respondents aged 46-50. In addition, the nurses who participated in this study, have more or less 1 to 30 years clinical work experiences. Of those respondents, 1 respondent has less than 1 year clinical experience, 7 respondents had 1 to 5 years experiences, 4 respondents had 1- 10 years, 4 respondents had 1-15 years, 5 respondents 1 - 20 years, 3 respondents had 1 to 25 years experiences, and 1 respondent had $1-30$ years of clinical experience. The majority of participants had 1 to 5 years of clinical work experiences in the Emergency Department (12 participants). Others, 4 respondents had less than 1 year clinical experiences in the Emergency Department, 3 respondents had $6-10$ years, 3 respondents had $11-15$ years, 1 respondent had 16 - 20 years, last, 2 respondents had $20-$ 25 years experience in the Emergency Department.

The experiments were conducted in hospital meeting room with consisting groups of respondent (maximum 6 people). This grouping aims to minimize disruption that may occur if the evaluation done by many people at the same time. Stimulus were employed on 22 inch LCD TV screen to achieve a good resolution and actual colors. Because of the hospital regulation was prohibited to disturb medical staff while they work and in order to get most likely the same situation of the work environment, the experiments were carried out before the nurses started duties. The data collection of mood and motivation questionnaires were carried out before the nurses started their tasks in the morning, day, and night shifts on November $10^{\text {th }}$ while the data collection of attitude questionnaire were conducted on November $25^{\text {th }} 2016$.

\section{RESULTS}

The data from the experiments were analyzed using normality test, Friedman non-parametric test, and Kruskal-Wallis non-parametric test (Field, 2009). Normality test was administered using Kolmogorov-Smirnov's test to examine the proportion of the data distribution on the basis of standard normal distribution. Friedman test was utilized to unravel the correlation between more than 2 groups (manipulated condition) of the same respondents to discover whether there were any different responses. Friedman test can be applied in the data which were not normally distributed. Kruskal-Wallis test was implemented to analyze the correlation among respondents of more than 2 groups and the dependent variables. In this study, the correlations which were examined were the correlations between forms of natural elements as independent variable and mood, motivation, and attitude as dependent variables in the context of nurses' work area.

\subsection{MOOD RESPONSE ANALYSIS}

ANOVA test consists of parametric and nonparametric tests. To select the appropriate test, normality test was performed to find out the data distribution. Mood response normality test possessed abnormal data which were found in the Conditions 2, 3, 5, and 6 with Shapiro-Wilk significance value ( $p$ value) at $<0.05$ while in the Conditions 1 and 4 , the Shapiro-Wilk significance value ( $p$ value) was at $>0.05$ which means that the data were normal. Even though the normal data existed, the abnormal ones were also present ; therefore, Friedman non-parametric test was needed.

The table of Friedman Test informed that mood response was obtained at Chi-Square (x2) value of 11.976 and the Monte Carlo significance value ( $p$-value) was at $0.032<0.05$. The results suggested that the difference in the forms of natural elements affected nurses' mood. In other words, the mood response changed significantly in response to the changes in the forms of natural elements. Because of that, Wilcoxon signed-rank test was needed to be performed in a post hoc test in order to find out the comparison of each condition.

Wilcoxon signed-rank test was utilized as a post hoc test to reveal the difference of mood response effect in each condition and the forms of other natural elements. Through Wilcoxon test (Table 1), it was found that there were several condition whose value was significant ( $\mathrm{p}$ value $<0.05$ ), namely:

1. The comparison between control variable (Condition 1) and the ceiling pattern (Condition 5) showed a significant value at 0.22 .

2. The comparison between the natural elements (Condition 2) and the wall pattern (Condition 4) showed a value at 0.20 and the ceiling pattern (Condition 5) indicated a significant value at 0.30 .

3. The comparison between the floor pattern 
(Condition 3) and the wall pattern (Condition 4) indicated a significant value at 0.07 and the natural elements on the ceiling (Condition 5) showed a significant value at 0.04 .

4. The comparison between the ceiling pattern (Condition 5) and the soft furnishing pattern (Condition 6) showed a significant value at 0.14

Table 1: Significance mood response

\begin{tabular}{|c|c|c|c|}
\hline No. & \multicolumn{2}{|c|}{ Comparison Condition / Variable } & $\begin{array}{c}\text { Exact } \\
\text { Sig. } \\
\text { (1- } \\
\text { tailed) }\end{array}$ \\
\hline 1. & $\begin{array}{c}\text { Condition 1 } \\
\text { (control } \\
\text { variable) } \\
\text { Condition 2 } \\
\text { (the } \\
\text { natural } \\
\text { element) }\end{array}$ & $\begin{array}{c}\text { Condition 5 } \\
\text { (the ceiling } \\
\text { pattern) }\end{array}$ &, 022 \\
\hline 2. & $\begin{array}{c}\text { Condition 4 } \\
\text { (the wall Pattern) }\end{array}$ &, 020 \\
\hline 3 & $\begin{array}{c}\text { Condition 5 } \\
\text { (the ceiling } \\
\text { pattern) }\end{array}$ &, 030 \\
\hline & $\begin{array}{c}\text { (the floor } \\
\text { pattern) }\end{array}$ & $\begin{array}{c}\text { Condition 4 } \\
\text { (the wall pattern) }\end{array}$ &, 007 \\
\hline 4 & $\begin{array}{c}\text { Condition 5 } \\
\text { (the ceiling } \\
\text { pattern) }\end{array}$ &, 004 \\
\hline & $\begin{array}{c}\text { Condition 5 } \\
\text { (the ceiling } \\
\text { pattern) }\end{array}$ & $\begin{array}{c}\text { Condition 6 } \\
\text { (the soft } \\
\text { furnishing } \\
\text { pattern) }\end{array}$ &, 014 \\
\hline
\end{tabular}

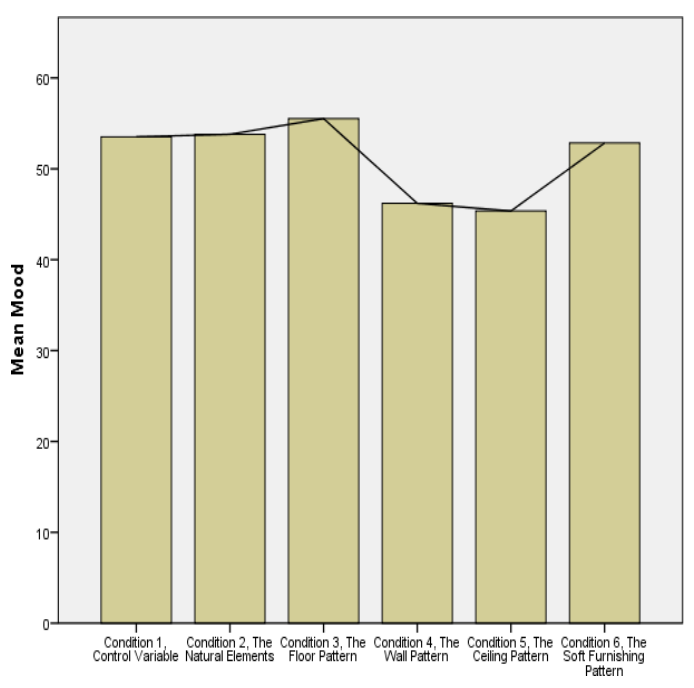

Diagram 1. Mood response's diagram

PANAS questionnaire which was used to measure mood had 7 Likert scales starting from the smallest value which represented the most negative response to the highest value which means the most positive response. To calculate the total value of mood response, it was decided that the higher the value, the more positive the mood response.
According to the bar chart (Diagram 1), it can be seen that there was a different mood response in each condition. Condition 3 (the average value was 55.52) was the condition whose mood evaluation value was the highest. This means that in the Emergency Department area, the floor pattern was a condition which obtained the most positive mood response. In contrast, Condition 5 depicting the ceiling pattern generated the least positive mood response as its average value was recorded at only 45.36 .

\subsection{MOTIVATION RESPONSE ANALYSIS}

Normality test towards motivation response unraveled that the data were not normal in the Conditions 2, 3, 4, 5, and 6 with Shapiro-Wilk significance value ( $p$ value) at $<0.05$ whereas the Condition 1 indicated Shapiro-Wilk significance value ( $\mathrm{p}$ value) at $>0.05$ which means that the data were normal. Although some data were normal, some were not. This situation required the researcher to perform Friedman non-parametric test.

The table containing the results of Friedman test informed that motivation response was obtained through Chi-Square value (x2) at 9.148 and through Monte Carlo significance value at $0.102>0.05$. Therefore, it can be concluded that the forms of natural elements did not have any significant influences on the nurses' attitude. Hence, Wilcoxon signed-rank test was needed to be performed as a post hoc test to unravel the comparison of each condition.

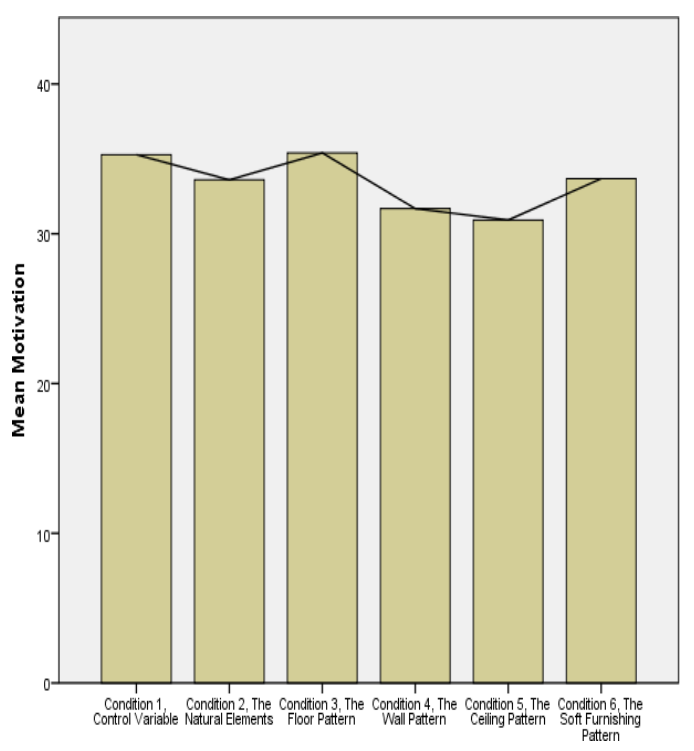

Diagram 2. Motivation response's diagram. 
Based on the bar chart (Diagram 2), it can be seen that there were different responses in motivation responses for each condition. Condition 3 (the average value was 35.40 ) was the condition whose motivation evaluation value was found to be the highest. It was therefore obvious that in the Emergency Department area, the floor pattern was the condition which triggered the most positive motivation response. The condition which earned the least positive motivation response was Condition 5, namely the ceiling pattern (the average value was 30.92).

\subsection{ATTITUDE RESPONSE ANALYSIS}

The attitude response normality test possessed data which were not normal found in Conditions 3, 4, 5, and 6 whose their Shapiro Wilk significant value ( $p$ value) was $<0.05$ while Conditions 1 and 2 had Shapiro-Wilk significant value ( $\mathrm{p}$ value) at $<0.05$ which means that the data were normal. Even though some data were normal, some were not. Thus, Friedman non-parametric test was needed.

The Friedman Test table indicated that attitude response was obtained through ChiSquare (x2) and the value was 5.835 while the Monte Carlo significance value was $0.319>0.05$. This can be concluded that the difference in the forms of natural elements did not give any significant influences toward the nurses' attitude. Therefore, Wilcoxon signed rank test as a post hoc test was needed to find out the comparison for each condition.

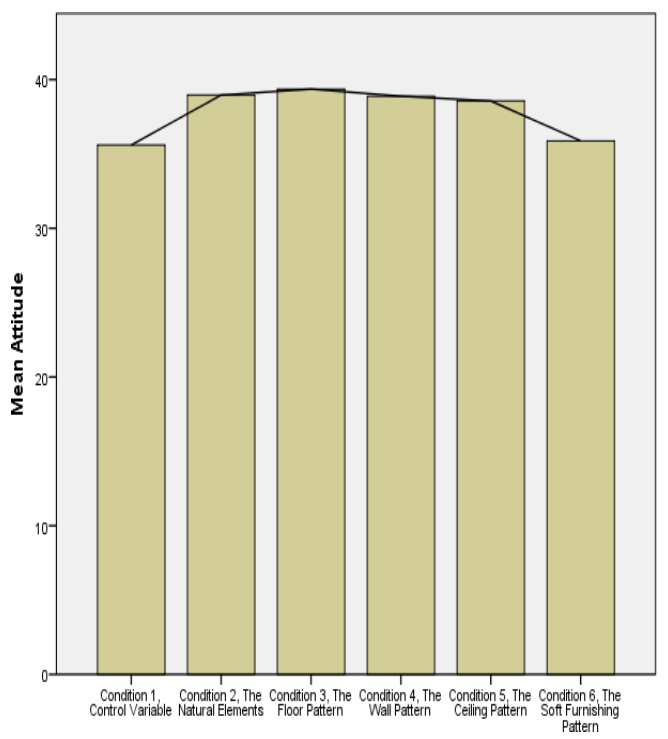

Diagram 3: Attitude response's diagram
According to the bar chart (Diagram 3), it can be seen that there were different results in the attitude response for each condition. Condition 3 (the average value was 39.36) was the condition which had the highest value with regard to the evaluation of the positive attitude, It was thus clear that the floor pattern was the most positively influential condition towards nurses' attitude. The condition which triggered the least positive attitude response was Condition 1 , or control variable (the average value was 35.60$)$.

\subsection{THE RESULTS OF CORRELATION ANALYSIS BETWEEN MOOD, MOTIVATION, AND ATTITUDE}

A correlation test was administered to reveal whether there was a correlation between mood, motivation, and work attitude. Based on the results of the correlation analysis between mood response and motivation, it was found that there was a positive correlation indicated by significance value at 0.637 (Table 2). This correlation was considered strong because the value was at $0.5>\mathrm{x}>0.75$ (Sarwono, 2009). This also means that there was a strong positive correlation between mood and motivation.

Mood response with a significance value at 0.709 (Table 2 ) means that the correlation direction was positive. In other words, when the mood value was higher, the attitude value became higher too and vice versa. With regard to the correlation strength, the correlation was considered strong because its value was at 0.50> x >0.75 (Sarwono, 2009). Therefore, it can be concluded that there was a strong positive correlation between mood and attitude in the context of nurses' work area.

Motivation response and attitude also exhibited a positive correlation. Its significance value was 0.713 (Table 2). This correlation was considered strong because it was recorded at $0.50>x>0.75$ (Sarwono, 2009). This means that there was a very strong positive correlation between attitude and motivation. 
Table 2: Correlation Between Mood, Motivation, and Attitude.

\begin{tabular}{|c|c|c|c|c|}
\hline & & Mood & Motivation & Attitude \\
\hline \multirow[t]{3}{*}{ Mood } & $\begin{array}{l}\text { Pearson } \\
\text { Correlation }\end{array}$ & 1 & $.637^{* *}$ & $.709^{* *}$ \\
\hline & $\begin{array}{l}\text { Sig. } \\
\text { tailed })\end{array}$ & & .001 & .000 \\
\hline & $\mathrm{N}$ & 25 & 25 & 25 \\
\hline \multirow[t]{3}{*}{ Motivation } & $\begin{array}{l}\text { Pearson } \\
\text { Correlation }\end{array}$ & $.637^{* *}$ & 1 & $.713^{* *}$ \\
\hline & $\begin{array}{l}\text { Sig. } \\
\text { tailed) }\end{array}$ & .001 & & .000 \\
\hline & $\mathrm{N}$ & 25 & 25 & 25 \\
\hline \multirow[t]{3}{*}{ Attitude } & $\begin{array}{l}\text { Pearson } \\
\text { Correlation }\end{array}$ & $.709^{* *}$ & $.713^{* *}$ & 1 \\
\hline & $\begin{array}{l}\text { Sig. } \\
\text { tailed })\end{array}$ & .000 & .000 & \\
\hline & $\mathrm{N}$ & 25 & 25 & 25 \\
\hline
\end{tabular}

**. Correlation is significant at the 0.01 level (2-tailed).

\section{DISCUSSION}

\subsection{DISCUSSION ON MOOD RESPONSE}

The floor pattern (Condition 3) with the average value at 55.52 became the strongest trigger of the positive mood responses. Job satisfaction towards work area could be associated with positive evaluation towards work environment (Totterdell \& Niven, 2014). This statement was in line with the theory posited by Fejld as cited in Capsari et al. (2006); that is, aesthetic elements was able to encourage nurses to perform better and to have stronger work satisfaction. It is possible due to the presence of positive mood. This statement also proved Ulrich's finding (as cited in Keniger et al., 2013) that the forms of natural elements positively affected human, in this case, nurses', psychological condition, such as the presence of good mood.

The ceiling pattern (Condition 5) with the average value at 45.36 was the condition which triggered the weakest mood response. This however was contradictory to the previous theory. This situation happened because the stimulus which played a role as the control variable (Condition 1) was presented in the first order during the experiment. Creswell as cited in Hastjarjo (2014), a within-subject- design research is a randomized experiment which requires random order of the stimulus. The stimulus which is not in random order, such as this study, will yield a result that negates previous studies. The next discussion will elaborate the combination of condition which shows significant correlations.

The different responses in the significant condition 1: The differences between control variable (Condition 1) and the ceiling pattern (Condition 5) were very strong. Control variable's average value, namely 53.52, was higher than that of on the ceiling, namely 45.36. This finding can be interpreted than the presence of the natural elements did not affect the nurses' mood who were assigned in the Emergency Department during the night shifts. This statement did not corroborate Smith and Pitt's theory as cited in Danurdoro (2013) who stated that a condition containing natural elements is better than a condition where natural elements are completely absent. The different finding between this study and that of Smith and Pitt is that in this study nurses who became the participants were dominated by those who had clinical work experience in the emergency department for 1-5 years and 1-25 years. They probably were already accustomed to the work environment in this department so that their sense of place was strong. The sense of place essentially contributed to the development of positive or negative emotion depending on the cognitive, emotion, and symbol of a place interpreted by a person (Hashemnezhad et al., 2012). A place is not merely a physical characteristic that distinguishes it from another place. According to Steele as cited in Hashemnezhad et al. (2012), a place is a physical parameter for the sense of place's aspects, namely size, scale, components, diversity, texture, decoration, color, odor, noise, and temperature. He also explained that identity, history, fun, mysterious, pleasant, wonderful, security, vitality, and memory also influence the ways a person communicate with a place. From the aforementioned explanation, it can be concluded that nurses had a more positive sense of place on control variable than the ceiling pattern.

The different responses in the significant conditions 2: The differences between natural elements (Condition 2) and the wall pattern along with the ceiling pattern (Condition 5) were strong. The natural elements had a higher average value, namely 53.80, than that of the natural elements on the wall and the natural elements on the ceiling, namely 45.36. This finding indicated that the presence of the real natural elements positively affected the nurses' mood who worked in the Department of Emergency during the night shifts. This statement corroborated Mariana et al. (2015) 
who revealed that decorative plants positively influenced workers' psychological condition such as improving their mood (Keniger et al., 2013). Nevertheless, the real natural elements did not optimally trigger mood response unless the natural elements were placed on the floor. The position of the plants which were installed in the top column became a reason why the real natural elements were less likely to lead to a positive mood response. It is worth noting that human beings have an optical view to see things before their eyes at 60 degree horizontal perspective. However, if this fact is associated with the average height rate of the Indonesians and the ceiling's height in the Emergency Department $(340 \mathrm{~cm})$, their eye-view level was not projected to half of the room's height. Therefore, nurses' eye could only capture the stimulus located on the same eye level in the room and in the bottom of the room as opposed to the stimulus positioned on the top of the room. In addition to the position of the plants, the quantity aspect of the stimulus also affected the nurses' mood response.

The different responses in the significant conditions 3: The differences between the floor pattern(Condition 3) and the wall pattern (Condition 4) along with the ceiling pattern (Condition 5) were strong. The floor pattern possessed a higher average value, namely 55.52 , than that of the wall pattern, namely 46.20 , and that of the ceiling pattern, namely 45.36. This finding indicated that the floor pattern more positively contributed to the nurses' mood than the wall and the ceiling pattern. This finding agreed with Keniger's study (2013) which revealed that the natural elements were able to improve the mood. The floor pattern was positioned below the eye level; therefore, it enabled nurses to see the stimulus situated on the bottom of the room than the stimulus positioned on the top of the room. Even though the floor pattern only exhibited strong differences from the wall and the ceiling pattern, this condition was still better to apply than the condition without any natural elements, natural elements, and soft furnishing pattern.

The different responses in the significant conditions 4: The difference between the soft furnishing pattern (Condition 6) and the wall pattern (Condition 4) along with ceiling pattern (Condition 5) were strong. The soft furnishing pattern had a higher average rate, namely 52.84, than the ceiling pattern, namely 45.36 . This finding indicated that the soft furnishing pattern gave a more positive effect for the nurses' mood than the ceiling pattern. This result was in line with Ergunder's finding (2012) which unraveled that soft furnishing triggered the feeling of comfort and improved the satisfaction level towards the interior. Nevertheless, the wall and the ceiling pattern still had natural elements in them. This was due to the position of the soft furnishing (curtains) which was easily captured by the nurses' eyes so that the nurses could directly see it. In contrast, the position of the wall pattern (on the column and on the wallpapers of the medical treatment rooms) and the ceiling pattern made it difficult to be directly seen by the nurses' eyes. Although the wall pattern was supposed to be easily viewed, they were not really shown during the night shifts in the Emergency Department because their presence was blocked by the curtains. Specifically, the majority of the curtains were closed during the night shift; as a result, the soft furnishing pattern (curtains) were more easily viewed by the nurses than the wall pattern.

From the four aforementioned comparisons, it can be further interpreted that the presence of particular forms of natural elements could boost the mood response of the nurses who worked in the Emergency Department during the night shifts. However, the effect of manipulating the wall and on the ceiling by adding some natural elements on them did not really trigger mood response as opposed to the condition where the natural elements were absent. This situation could be caused by the influence of the nurses' perspective towards the characteristics of their workplace/external factors. This statement corroborated Vries et al. (2010), "people often prefer familiar stimuli, presumably familiarity signal safety." Furthermore, "positive mood signals a safe environment, whereas negative mood signals a unsafe environment." Evaluation process towards the physical environment would lead to a perception which made the nurses felt more familiar with the existing condition so that positive mood was developed. In addition, according to Fish (as cited in Firdaus, 2005), it was reported that the cognitive factor/internal positive factor of the workers, in this study nurses, which was high could overcome the negative impacts of working in the night shifts for their physical and psychological well beings. As a result, the influence of external environment became insignificant.

\subsection{DISCUSSION ON MOTIVATION RESPONSE}


Based on the data analysis, it can be seen that there were some differences with regard to positive motivation responses even though these differences were not strong. The floor pattern became the strongest trigger of positive motivation response with the average value at 35.40. Although there were no significant differences among each condition in the motivation response, the floor pattern was the best condition as opposed to others.

This finding also proved that the forms of natural elements gave positive effects towards the nurses' psychological condition (Keniger, 2013). In this case, psychological condition as well as the existence of work motivation. The ceiling pattern (Condition 5) was the weakest trigger of motivation response with the average value at 30.92 . This finding was contradictory to the previous theory. This situation occurred because the control variable's stimulus (Condition 1) was played in the first order during the experiment. Based on Creswell, for a within-subject-research, it requires a randomized experiment so that the order must not be in chronological order (Hastjarjo, 2014). As a consequence, in this study, the stimulus order which was not randomized yielded results which did not agree with the previous studies

The results on motivation response toward the condition of the natural element forms did not show any significant differences. The theoretical reason underlying this finding was that motivation was a psychological construction which could not be directly observed and needed mood as its component to observe it (Toure-Tillery \& Fishback, 2014).

\subsection{DISCUSSION ON ATTITUDE RESPONSE}

According to the data analysis, there were still differences on the positive attitude response even though the differences were not obvious. The floor pattern (Condition 3) was the strongest trigger of the positive attitude response with its average value at 39.36. Although the differences among the conditions in the attitude response were absent, the floor pattern was the best condition to apply compared to other conditions.

This statement proved that the forms of natural elements gave a positive effect towards the nurses' psychological well being (Ulrich, 2001) and triggered good behavior (Keniger, 2013). Behavior is a conative component which underlies the presence of attitude (Notoatmojo, 2003). Control variable (Condition 1) whose average value was 35.60 was the condition without natural elements which very minimally invited attitude response. This finding was in accordance with Smith and Pitt's theory (as cited in Danurdoro, 2013) which stated that the presence of natural elements is definitely better than no natural elements at all. This finding was totally different with the result of mood response because the weakest mood response was found on the ceiling. The reason was that a condition without natural elements was presented in the last order during the attitude experiment so that it led to the finding which corroborated the previous studies (Hastjarjo, 2014).

The result of attitude response analysis in every condition of the natural element forms did not exhibit any significant differences. The underlying theory of this finding was that attitude is a psychological construction which cannot be directly observed and needs mood as its component to observe it (Santillan et al., 2012).

\subsection{DISCUSSION ON THE CORRELATIONS AMONG MOOD, MOTIVATION, AND ATTITUDE}

Based on the result of correlation analysis, the data showed that there were very strong correlations between mood and motivation, a very strong correlation between mood and attitude, and a strong correlation between motivation and attitude. The aforementioned statement was in line with the hypothesis of this study positing that the natural elements would develop positive mood which fostered work motivation and improved the positive attitude of the nurses who worked in the Emergency Department during the night shifts. It is an accordance with Robbin \& Judges (2015) theory that mood and emotion affect motivation and attitude. The organizations that promote positive moods at work are likely to have more motivated workforce and positive attitude. Likewise, positive work motivation would boost mood and attitude while positive attitude would trigger the improvement of mood and work motivation.

\section{CONCLUSION}

This study found that the floor pattern became the best condition compared to the natural elements implemented in other medium because it enabled the escalation of mood, motivation, 
and work attitude of the nurses who worked in the Emergency Department during the night shifts. Based on the results of mood and motivation response analysis showed some contradictory statements with the previous theory in this field (i.e. natural elements are able to restore people's psychological condition), these contradictions were likely caused by the nurses' perception towards their physical workplace / external factors. The result of the evaluation process towards physical environment was a perception which made the nurses feel familiar with the existing condition. As a consequence, it informed positive mood that signals a safe environment (Vries et al., 2010). In addition, based on McCarty, Power, \& Greiner (Tomioka, Morita et al., 2011; as cited in Sahrain et al., 2013), nurses who had extensive clinical work experience were able to adapt to their physical work environment and to overcome stress due to the routine work pressure. Since nurses' tasks are strongly related with saving people's lives and giving health care services, these findings definitely requires nurses to have good psychological quality compared to other professions. Excellent psychological quality of a nurse is likely to cause him/her to consider the work physical environment less important.

The experiment procedures of attitude response in this study was the most appropriate. On the basis of the data on the attitude response, it could be concluded that this study agreed with Ulrich's theory (2002) postulating that green space was able to restore physical and psychological needs of human beings. These psychological needs are as well as improving mood to boosting work motivation and positive attitude (Robbin \& Judges, 2015). The finding of this study was also in line with the theory posited by Capsari et al. (2006) stating that aesthetic elements were able to make nurses to have higher work performance and better work satisfaction. Moreover, the finding of this study also corroborated Ergunder's theory (2012) indicating that soft furnishing triggered the feeling of comfort and increased satisfaction of the people in the room toward the room interior. This study also proved the previous studies conducted by Smith \& Pitt as cited in Danurdoro (2013) that the presence of natural elements was still better than the complete absence of these elements.

This study revealed that every natural element in the interior had a particular influence to trigger mood, motivation, and attitude responses of the nurses who worked in the
Emergency Department during the night shifts. The presence of work motivation (Adjei et al.,2016) and positive attitude (Shahab, 2014) among the nurses would improve their performance so that it would lead to better health care services.

\section{SUGGESTIONS}

There were several challenges when the experiments for this study were performed. The first challenge was the difficulty in obtaining an official permission to do research from the hospital. The next obstacle was that the number of studies about psychological design conducted in health care facilities in Indonesia was (and is still) very limited. Nevertheless, this study was finally able to be conducted in Santo Borromeus Hospital. The limitation of this study was that some experiments did not follow the procedures when presenting the stimulus so that the results were not in accordance with the findings from the previous studies. The presentation of the stimulus by projecting it on the screen whose dimension was not big enough had also made the participants unable to maximally evaluate the stimulus. For future researches in this topic, it is suggested that procedures to administer the experiments must seriously be taken into account in order to obtain appropriate data.

This study also exhibited a limitation in its digital simulation design. The normal walking speed of a person is $1,06-1,93 \mathrm{~m} / \mathrm{s}$ but in this study the speed was set at $1,67 \mathrm{~m} / \mathrm{s}$. Digital stimulation was prepared at 32 frames per second but during the experiment, the duration was slowed down in order to adjust with people's walking speed. This situation had affected the quality of animation which became less smooth. Furthermore, the use of natural elements' materials had not yet considered the real characteristics of the materials. This made the digital animation less natural. For future studies utilizing digital stimulus, it is suggested that the walking speed, the position of eyelevel perspective, the characteristics of materials, and real motion factors must be strongly taken into consideration. It is also worth noting that the results of this study cannot be generalized to nurses' of other hospitals because this study only focused on the nurse work in the Emergency Department at Santo Borromeus Hospital.

This research indicates that natural elements influence worker's responses, especially Emergency Department Nurses during the 
night shift. However, there are possibilities that other dimension could influence, such as natural element's material characteristic, lighting, social dimension, and perception, therefore it needs further research. The exact amount of respondent (the more are the better) and other hospital study case are required to understand the difference of the impact of the natural element's forms toward nurses' psychological factor. From industry perspective, similar experiment can be done by considering application technic of natural element's form on Emergency Department, such as material characteristic, the dimension of the natural elements, illumination, etc. Besides that, industries could produce material based on hospital's building procedure and natural element pattern to help increasing mood, motivation, and nurses' attitude.

The quality of nurses' psychological factor is often neglected by hospital management, especially Emergency Department nurses that have heavier workload that other department. It is important to conduct similar research that steep about ways to improving psychological quality factor of medical staff. The next research needs to be supported by newest technology media in order to produce better innovation for increasing psychology quality of medical staff.

\section{REFERENCES}

Azka, Nabila. (2016). Pengaruh Komposisi tanaman hidroponik dalam hunian bangunan tinggi terhadap respon relaks masyrakat urban. Postgraduate Thesis of Faculty Art and Design, Bandung Institute of Technology, Bandung.

Adjei, K. A., Emmanuel, O., and Forster, O. M. (2016). The impact of motivation on the work performance of health workers (Korle Bu Teaching Hospital): Evidence from Ghana. Hospital Practices and Research. 1(2):47-52.

Aghdam, M. A., Hassankhani, H., Zamanzadeh, V., Khameneh, S., and Moghaddam, S. (2013). Knowledge and performance about nursing ethic code from nurses' and patient perspective in Tabriz Teaching Hospital. Iran. Journal of Cating Sciences, 2(3): 219- 227.

Ansari, Z. M., Yasin, H., Zehra, N., and Faisal, A. (2015). Occupational stress among emergency department (ed) staff and the need for invesment in health care; a view from pakistan. Bristish Journal of
Medicine \& Medical Research, 10(10):19.

Berman, M. G., Jonides, J., dan Kaplan, S. (2008). The cognitive benefits of interacting with nature. Psychol, Sci. 25: 249-259.

Bringslimark, T., Hartig, T., dan Patil, G. G. (2007). Psychological benefits of indoor plants in workplace: putting experimental results into context. HortScience, 42(3):581-587

Boughattas, W., Maalel, O. E., Chikh, R. B., Maoua, M., Houda, K., Braham, A., Rhif, H., Chatii, S., Debabbi, F., Dogui, M., and Mrizak, N. (2014). Hospital night shift and its effects on quality of sleep, the quality of life, and vigilance troubles among nurse. International Journal of Clinical Medicine, 5: 572-583.

Caspari, S., Eriksson K., dan Naden, D. (2006). The aesthetic dimension in hospital - an investigation into strategic plans. International Journal of Nursing Studies, 43: 851-859.

Danurdoro, D. H. (2013). Nuansa vegetasi pada sun screen sebagai pembentuk persepsi dan sikap positif pada area kerja kantor. Postgraduate Thesis of Faculty Art and Design, Bandung Institute of Technology, Bandung.

Dobre, O. I. (2013). Employee motivation and organizational performance. Review of Applied Socio- Economic Research, 5(1): 53. ISSN: 2247-6172.

Ergunder, T. (2012). The importance of soft furnishings in interior space. Pilot study living spaces. Master Thesis of Science in Interior Architecture, Institute of Graduate Studies and Research.

Field, Andy. (2009). Discovering statistic using SPSS (3rd ed). London: Sage Publication.

Firdaus, H. (2005). Pengaruh shift kerja terhadap kejadian stres kerja pada tenaga kerja di bagian produksi pabrik kelapa sawit PTPN 4 Kebun Pabatu Tebing Tinggi Tahun 2005. Graduate Thesis, FKM-USU, Medan.

Fraenkel, J. R., Wallen, N. E., Hyun., H. H. (2012). How to design and evaluate research in education (8th ed). America, New York: Mc Graw Hill

Hashemnezhad, H., Heidari, A. A., dan Hoseini, P. M. (2012). Sense of place and place attachment. International Journal of Architecture and Urban Development, 3 (1): 4-12.

Hastjarjo, D. T. (2014). Rancangan eksperimen acak. Buletin Psikologi, Fakultas Psikologi Universitas Gadjah Mada, 22 
(2): $73-76$.

Hitchings, R. (2009). Indoor office worker and outdoor nature, economic \& social research council. UCL Department of Geography, Univesity College London.

Kamaruzzaman, S.N., dan Sabrani, N.A. (2011). The effect of indoor air quality (iaq) towards occupants' psychological performance in office buildings. Jurnal Reka bentuk dan Binaan, 4: 4961.

Keniger, L. E., Gaston, K. J., Irvine, K. N., dan Fuller, R. A. (2013). What are the benefits of interaction with nature? International Journal of Enviroment Reasearch and Public Health.

Notoatmodjo, S. (2003). Pendidikan dan perilaku kesehatan. Jakarta: Rineka Cipta.

Mariana, H. A., Ciobanu, I., Cicevan, R., Neascu, I., dan Cantor, M. (2015). Image of ornamental plants in work enviroments and their effect on employess. Agriculture Science and Practice, 3(4): 95-96.

Mosadeghrad, A. M. (2014). Factors influencing healthcare service quality. Int J Health Policy Manag, 3(2): 77-89.

Musa, S., Ziatdinov, R., and Griffiths, C. (2013). Introduction to computer animation and its possible educational applications. Retrospection of History of Education to The Future in The Interdisciplinary Dialogue among Didactics of Various School Subjects, 1: 177-205.

Robbins, S.P., and Judge, T. A. (2015): organizational behavior (16th ed). New Jesey: Pearson Education, Inc.

Sahraian, L., Davidi, F., Bazrafshan, A., dan Javadpour, A. (2013). Occupational stress among hospital nurses: comparison of internal, surgical, and psychiatric wards. International Journal of Community Based Nursing and Midwifery: 1 (4): 182190.

Said, R. M., Abed, F. A., \& Abdo, M. L.(2013). Work motivating factors as identifed by nurses in children hospital at Elmonira and Specialized Pediatric Hospital Cairo University. Medical Journal Cairo University, 81(2): 27-31

Santillan, A. G., Gracia, E. M., Castro, J. C.,M Abdala, J. H. Z., \& Trejo, J. G. (2012). Cognitive, affective and behavioral components that explain attitude toward statistics. Journal of Mathematics Research; vol 4: 8- 16.

Sarwono, J.. (2009). Statistik itu mudah: panduan lengkap untuk belajar komputasi statistik menggunakan SPSS 16. Yogyakarta : Universitas Atma Jaya.

Shahab, M. A. (2014). The influence of leadership and work attitudes toward job satisfaction and performance of employee. International Journal of Managerial Studies and Research, 2(5): 69-77

Sorongan, C. H., Rumampuk, J, and Lintong, F. (2014). Hubungan panjang tungkai dengan kecepatan berjalan pada siswa Sekolah Menengah Atas Negero 6 Manado. Jurnal e- Biomedik, 2(1): 1-9

Totterdell, P. and Niven, K. (2014). Workplace moods and emotions: a review of research, Chaelerston. SC: Createspace Independent Publishing.

Toure-Tillery, M. \& Fishbach, A. (2014). How to measure motivation: a guide for the experimental social psychologist. Social and Personality Psychology Compass, 8(7): 328-341.

Ulrich, R. S. (2001). Effects of healthcare environmental design on medical outcomes. In A. Dinali (Ed.) Design and Health: Proceeding of Second International Conference on Health and Design.

Ulrich, R. S. (2002). Health benefits of gardens in hospital. Plant for People, International Exhibition Floriade, pp. 1-10.

Vries, M., Hollans, R. W., Chenier, T., Starr, M. J., and Winkielman, P. (2010). Happiness cools the glow of familiarity: psychophysiological evidence that mood modulates the familiarity- affect link. Psychol Sci, 21(3):321-328.

Watson, D., Clark, L. A., \& Tellegen, A. (1988). Development and validation of brief measures of positive and negative affect: The PANAS scales. Journal of Personality and Social Psychology, 54 (6): 1063-1070 


\section{ATTACHMENT C MOTIVATION QUESTIONAIRE}

\section{Motivation Quationaire}

Do you agree by working in the room as the screen shown will encourage as stated below? Indicate by choosing the scale below! If strongly agree give number (7), somewhat agree (6), slighty agree (5), abstain (4), slighty disagree (3), somewhat disagree (2), strongly disagree (1)!

\begin{tabular}{|c|c|c|c|c|c|c|c|c|}
\hline \multirow[t]{2}{*}{ No. } & \multirow[t]{2}{*}{ Motivation } & \multicolumn{7}{|c|}{ Scale } \\
\hline & & 1 & 2 & 3 & 4 & 5 & 6 & 7 \\
\hline 1 & $\begin{array}{l}\text { I feel empathy for every patient that I } \\
\text { receive }\end{array}$ & & & & & & & \\
\hline 2 & $\begin{array}{l}\text { I feel I can concentrate to identify the } \\
\text { results of medical records }\end{array}$ & & & & & & & \\
\hline 3 & $\begin{array}{l}\text { I always want to feel ready to serve the } \\
\text { patients well }\end{array}$ & & & & & & & \\
\hline 4 & $\begin{array}{l}\text { I always want to feel ready to help and } \\
\text { assist physicians currently serving } \\
\text { patients }\end{array}$ & & & & & & & \\
\hline 5 & $\begin{array}{l}\text { I can concentrate when writing medical } \\
\text { records / reports / documentation of } \\
\text { nursing }\end{array}$ & & & & & & & \\
\hline 6 & $\begin{array}{l}\text { I always want to feel ready to take care, } \\
\text { identify the patient's condition, and help } \\
\text { patients }\end{array}$ & & & & & & & \\
\hline
\end{tabular}

\section{ATTACHMENT D ATTITUDE QUESTIONAIRE}

\section{Attitude Questionnaire}

Do you agree by working in the room as the screen shown will encourage as stated below? Indicate by choosing the scale below! If strongly agree give number (7), somewhat agree (6), slighty agree (5), abstain (4), slighty disagree (3), somewhat disagree (2), strongly disagree (1)!

\begin{tabular}{|c|c|c|c|c|c|c|c|c|}
\hline \multirow[t]{2}{*}{ No. } & \multirow[t]{2}{*}{ Attitude } & \multicolumn{7}{|c|}{ Scale } \\
\hline & & 1 & 2 & 3 & 4 & 5 & 6 & 7 \\
\hline 1 & I want to get in the ER hospital early & & & & & & & \\
\hline 2 & I tend to want to do my job seriously & & & & & & & \\
\hline 3 & $\begin{array}{l}\text { I want to fulfil my responsibilities as best } \\
\text { as possible }\end{array}$ & & & & & & & \\
\hline 4 & $\begin{array}{l}\text { I enjoy working together with my co- } \\
\text { workers }\end{array}$ & & & & & & & \\
\hline 5 & $\begin{array}{l}\text { I want to help finishing my colleagues's } \\
\text { works. }\end{array}$ & & & & & & & \\
\hline 6 & $\begin{array}{l}\text { I want to maintain the integrity of the } \\
\text { work environment in the Emergency } \\
\text { Departement }\end{array}$ & & & & & & & \\
\hline 7 & $\begin{array}{l}\text { I want to encourage my colleagues to } \\
\text { maintain of the integrity of this work } \\
\text { environment. }\end{array}$ & & & & & & & \\
\hline
\end{tabular}

